\title{
MICROLEAKAGE AT THE COMPOSITE-REPAIR INTERFACE: EFFECT OF DIFFERENT ADHESIVE SYSTEMS
}

\author{
MICROINFILTRAÇÃO NA INTERFACE COMPÓSITO-REPARO: \\ EFEITO DE DIFERENTES SISTEMAS ADESIVOS
}

Andrea Nóbrega CAVALCANTI ${ }^{1}$, Catarina LAVIGNE², Céres Mendonça FONTES ${ }^{3}$, Paula MATHIAS ${ }^{3}$

1- DDS, MSc, Piracicaba Dental School, UNICAMP.

2- Undergraduate student of Dental School of Bahia University.

3- Assstant professor, Dental School of Bahia University.

Corresponding address: Paula Mathias - Departamento de Odontologia Restauradora - Dentística, Faculdade de Odontologia da Universidade Federal da Bahia, Avenida Araújo Pinho, n. 62, 41.110-150, Salvador-BA, Brasil.

Phone number: (71) 336-5776 (r. 227); Fax: (71) 355-0081 - E-mail: pmathias@yahoo.com

Received: March 05, 2004 - Accepted: April 16, 2004

\begin{abstract}
$T_{\mathrm{b}}$

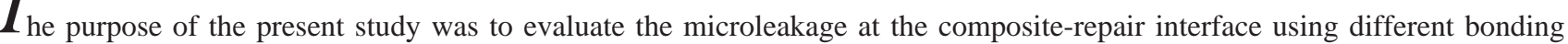
systems. Composite resin specimens (Filtek Z250 - 3M-ESPE) were divided into five groups ( $\mathrm{n}=20)$ according to the following bonding mechanism: C - control - etching with 35\% phosphoric acid; SB1 - etching and application of one coat of Single Bond (3M-ESPE); SB2 - etching and application of two coats of Single Bond (3M-ESPE); SMP1 - etching, application of Scotchbond Multi-Purpose primer (3M-ESPE) followed by the adhesive and, SMP2 - etching, application of Scotchbond Multi-Purpose adhesive (3M-ESPE) without the primer. Thereafter, all groups received new resin application. Samples were thermocycled (500 cycles $\left./ 5^{\circ} \mathrm{C}-55^{\circ} \mathrm{C}[ \pm 2]\right)$ and immersed for $4 \mathrm{~h}$ in $2 \%$ methylene blue buffered dye solution $(7.0 \mathrm{pH})$. Three examiners measured the extent of microleakage in a stereoscope microscope, using four representative scores. For all experimental groups, no significant difference in microleakage at the repair was identified by Kruskal-Wallis test $(p>0.05)$. Therefore, different types of bonding systems presented the same effect on the dye penetration along the repair interface.

Uniterms: Repair; Composite resin; Microleakage.
\end{abstract}

\footnotetext{
RESUMO

Q

objetivo do presente estudo foi avaliar o efeito de diferentes sistemas adesivos sobre a microinfiltração na interface de reparos em resina composta. Corpos-de-prova do compósito Filtek Z250 (3M-ESPE) foram divididos aleatoriamente em cinco grupos ( $n=20)$ de acordo com a forma de confecção do reparo: C - controle - condicionamento com ácido fosfórico a 35\%; SB1 - condicionamento ácido e aplicação de uma camada do agente de união Single Bond (3M-ESPE); SB2 - condicionamento ácido e aplicação de duas camadas de Single Bond; SMP1 - condicionamento ácido, aplicação do primer e do adesivo do sistema Scotchbond Multipurpose Plus (3M-ESPE) e SMP2 - condicionamento ácido e aplicação apenas do adesivo do ultimo sistema. O reparo foi finalizado com a inserção de nova camada do compósito restaurador. As amostras foram termocicladas (500 ciclos / 5-55 $\left.{ }^{\circ} \mathrm{C}[ \pm 2]\right)$ e imersas por $4 \mathrm{~h}$ em solução tamponada de azul de metileno $2 \%$ (pH 7,0). A penetração do corante na interface do reparo foi avaliada em lupa estereoscópica (40x) por três examinadores utilizando quatro escores representativos. A análise estatística não encontrou diferenças entre os grupos experimentais (Kruskal-Wallis / p > 0.05). Dessa maneira, os diferentes sistemas adesivos mostraram comportamento semelhante sobre a microinfiltração na interface do reparo.

Unitermos: Reparo; Resinas compostas; Microinfiltração.
} 


\section{INTRODUCTION}

Repair is an alternative to the total replacement of a defective composite resin restoration. Indications for such treatment include fractures ${ }^{4}$; discolored or worn areas ${ }^{2}$; poor anatomic form; secondary caries; tooth fracture and pain/sensitivity ${ }^{12}$. Also, according to Turner, et al. ${ }^{23}$ (1993) repair situations occur regardless of the technique used or type of resin; whether macrofill, hybrid, microfill, chemically cured, light-cured, heat-cured, direct or indirect composite resin.

Complete removal of defective composite restorations may lead to larger cavities with further loss of tooth structure ${ }^{6,10}$. Such treatment involves difficulties like recognizing the composite-tooth interface and the need for removing previously etched enamel to enable a new bonded restoration to be made ${ }^{18,20}$. In addition, total replacement increases pulpal trauma and the cost of the procedure ${ }^{6}$.

However, the repair procedure can also result in weaker restorations ${ }^{18,20}$. Therefore, successful resin repair requires development of an adequate interfacial bond between the old and new resins. Several composite repair studies have shown that a surface treatment and the use of an intermediate

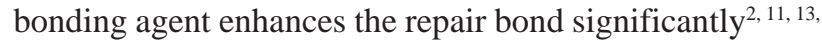
$15,16,19,22$. While surface roughness promotes mechanical interlocking, the bonding agent advances surface wetting and chemical bond with the new composite ${ }^{2}$.

Various surface treatment methods and bonding agents have been indicated for the repair procedure ${ }^{2,11,13}$. The choice of a surface treatment seems to depend on the substrate surface to be repaired (i.e. the hydrofluoric acid seems to have little effect on microfilled resins $)^{6}$. However, there is little information regarding the behavior of different bonding systems on the repair procedure.

According to Lewis, et al. ${ }^{10}$ (1998) the efficiency of the repair is related to the magnitude of the bond strength obtained at that interface. However, a clinically adequate bonding should also be able to prevent microleakage at its interface $^{7}$. This leakage leads to deterioration of the bond and accelerates failure ${ }^{4,17}$. In addition, interfacial staining could compromise esthetics, especially in anterior teeth, and as a result the entire restoration needs to be replaced ${ }^{6}$.

Therefore, this study aimed at evaluating the effects of different bonding systems on microleakage at the compositerepair interface using a qualitative dye penetration analysis.

\section{METHOD AND MATERIALS}

Composite resin specimens were made in a quadrangular acrylic resin mold with an internal space of 6 x 6 x $2 \mathrm{~mm}$. A removable acrylic resin spacer was inserted to make halflength specimens ( 3 x 6 × 2mm) in the first part of this study. Initially, half the mold was filled with composite resin Filtek Z250 (3M-ESPE, St. Paul, MN, USA), in a single increment. A glass microscope slide was placed over the mold and pressed to remove excess material. Each specimen was lightcured through the slide for 10 seconds using a visible lightcuring unit (Optilight 600 - Gnatus, Riberão Preto, SP, Brazil). The tip of the curing light was kept at a 90-degree angle to the top surface, in contact with the glass to achieve maximum curing depth. After the top surface had been cured, the specimens were carefully removed from the mold and another light exposure of 40 seconds was applied to specimen surfaces.

A hundred half-length specimens were then stored in artificial saliva ${ }^{21}$ at $37^{\circ} \mathrm{C}$ for ten weeks in order to restrict bond mechanism to micromechanical retention, thus avoiding chemical bonding between methacrylate radicals from substrate resin and repair resin ${ }^{23}$. After this period, they were randomly allocated into five groups according to the following surface treatment methods $(n=20)$ :

Group C: control - no bonding agent application;

Group SB1: application of one coat of Single Bond (3MESPE, St. Paul, MN, USA) cured for 10 seconds;

Group SB2: application of two consecutive coats of Single Bond cured for 10 seconds;

Group SMP1: application of one coat of Scotchbond Multi-Purpose primer (3M-ESPE, St. Paul, MN, USA) with 5 seconds of delay, and followed by the SMP adhesive (3MESPE, St. Paul, MN, USA), cured for 10 seconds;

Group SMP2: application of one coat of Scotchbond

TABLE 1- Materials used in this study

\begin{tabular}{llll}
\hline Material & Manufacturer & Lot no. & Chemical composition \\
\hline Filtek Z250 & 3M ESPE, St Paul, MN, USA & A1 - OCJ & Bis-GMA, UDMA, Bis-EMA \\
Single Bond & 3M ESPE, St Paul, MN, USA & 9ED & Bis-GMA, HEMA, PAA, water, ethanol \\
$\begin{array}{l}\text { Scotchbond Multi- } \\
\text { Purpose Primer }\end{array}$ & 3M ESPE, St Paul, MN, USA & OYE & HEMA, PAA, water \\
$\begin{array}{l}\text { Scotchbond Multi- } \\
\text { Purpose Adhesive }\end{array}$ & 3M ESPE, St Paul, MN, USA & OLR & Bis-GMA, HEMA \\
\hline
\end{tabular}

Abbreviations: Bis-GMA: bisphenol-glycidil methacrylate; UDMA: urethane dimethacrylate; Bis-EMA: Ethoxylated bisphenolA-dimethacrylate; HEMA: 2-hydroxyethyl methacrylate; PAA: polyalkenoic acid copolymer. 
Multi-Purpose adhesive cured for 10 seconds, without previous application of the SMP primer.

Materials used and their chemical composition are described in Table 1.

Before the bonding procedure, each specimen's surface, including those of the control group, was air-abraded with 50-ìm aluminum oxide particles for 10 seconds (Microetch Bioart, São Carlos, SP, Brazil). Then, they were rinsed with distilled water for 20 seconds and dried with compressed air for 10 seconds. The samples were cleaned with 35\% phosphoric acid etchant (3M-ESPE, St. Paul, MN, USA) for 60 seconds, rinsed vigorously with tap water, and dried with oil-free compressed air. After the surface treatment, the bonding procedure was performed and each specimen was placed back into the mold with no spacer inserted. The repair composite was applied and cured as described above, completing repair procedure. A dark shade was chosen as the repair material (C4) and a lighter one as the substrate (A1) - so that there could be better assessment of the repair interface. Finishing procedures were made after 24 hours with a decreasing abrasive sequence of aluminum oxide disks (Sof-Lex - 3M-ESPE, St. Paul, MN, USA).

The repaired specimens were removed from the mold and stored in distilled water for 24 hours. The external surfaces of each sample were coated with two layers of nail varnish, with the exception of the side directly exposed to the curing light unit. Then they were thermocycled for 500 cycles between $5^{\circ} \mathrm{C}( \pm 2)$ and $55^{\circ} \mathrm{C}( \pm 2)$ with a one-minute dwell time at each temperature and then immersed for 4 hours in a $2 \%$ methylene blue buffered dye solution ( $\mathrm{pH} 7.0)$.

\section{Microleakage}

The samples were transversely sectioned with a doublefaced diamond disk (n.7020, KG Sorensen, Barueri, SP, Brazil). Three independent examiners measured the extent of dye penetration at the composite-repair interface in a stereoscope microscope (40x) according to the following scores:

$0=$ absence of dye penetration;

$1=$ up to $1 / 2$ of repair interface;

$2=$ over $1 / 2$ of repair interface, without total involvement;

3 = complete repair interface involvement.

The three evaluators were pre-calibrated before the onset of this project. The inter-rater reliability of the scores was expressed as Cohen's Kappa ${ }^{14}$. Data were analyzed statistically using a non-parametric Kruskal-Wallis test at a significance level of $5 \%{ }^{5,8}$.

\section{RESULTS}

The overall values of the inter-rater reliability ranged from good to excellent ( 0.77 to 0.90 Kappa values).

The median scores of all experimental groups were not significantly different from one another (Kruskal-Wallis; $\mathrm{p}$ $>0.05$ ). Results showed little or no dye penetration at the repair interface - including the control group (Score variation from 0 to 1 ) (Table 2).

\section{DISCUSSION}

Microleakage at the composite-repair interface can compromise the repair procedure, as the interfacial staining damages esthetics and the leakage leads to deterioration of the interface $\mathrm{e}^{4,6,17}$. Therefore, repair techniques and materials chosen should be able to increase the repair strength and also to promote an adequate interfacial sealing.

This study was conducted to determine the effect of different bonding systems on the composite-repair microleakage. The evaluation comprised a single-component system, applied in one and two coats (Single Bond), a multicomponent system (ScotchBond Multi-Purpose) and an unfilled resin (ScotchBond Multi-Purpose Adhesive). Singlecomponent bonding agents seem to simplify the bonding procedures and save time, however there is little information about their performance on composite repair.

Results indicated that the bonding systems used (SB1, SB2, SMP1, SMP2) did not show a significant difference in dye penetration along the repair interface. All groups demonstrated a good interfacial sealing, presenting scores ranging from 0 to 1 - including the control group, only airabraded with aluminum oxide particles.

A previous study demonstrated that microleakage at the composite-repair interface was not influenced by different surface treatments ${ }^{3}$. As bond application was standardized

TABLE 2- Distribution of dye penetration scores

\section{Groups}

Control (C)

Single Bond 1 (SB1)

Single Bond 2 (SB2)

Scotchbond Multi-Purpose (SMP1)

Scotchbond Multi-Purpose Adhesive (SMP2)
Score

1

5

6

3

4

20
2

3

* Kruskal-Wallis / p > 0.05 
for all groups, those authors suggested that it may have been the main reason for the groups' behavior, masking possible effects of the surface treatments tested (air abrasion with 50 -ìm aluminum oxide particles, roughing with diamond bur, and jet prophylaxis with sodium bicarbonate particles).

On the other hand, the present study indicated that air abrasion of the repair surface with 50-ìm aluminum oxide particles (control group) was also able to prevent dye penetration at the repair interface. This group presented no significant differences from the other experimental groups. Relating this results with those of the previous study ${ }^{3}$, it can be suggested that both surface treatment (air abrasion) and bond application present good results, preventing microleakage at the composite-repair interface. In addition, considering that their association also enhances repair bond significantly ${ }^{11,18,23}$, it should be established that both of them are essential to optimize the repair procedure.

Otherwise, the results of this study are for repaired specimens stored for 24 hours in water and aged by 500 thermal cycles. Longer storage or increased thermocycling may present other results ${ }^{1,9}$. Also, the relationship between microleakage and bond strength on the repair procedure remains undetermined. Therefore, further studies should be conducted to investigate the effect of these variables on composite repair.

\section{CONCLUSIONS}

Within the limitations of this in vitro study, the following conclusion may be drawn:

- The type of bonding system did not influence microleakage at the composite-repair interface.

\section{ACKNOWLEDGMENTS}

The authors thank KG Sorensen and 3M-ESPE for material support for this investigation.

\section{REFERENCES}

1- Azarbal P, Boyer DB, Chan KC. The effect of bonding agents on the interfacial bond strength of repaired composites. Dent Mater 1986; 2(4):153-5.

2- Brosh, T, Pilo R, Bichacho N, Blutstein R. Effect of combinations of surface treatments and bonding agents on the bond strength of repaired composites. J Prosthet Dent 1997; 77(2):122-6.

3- Cavalcanti AN, Lobo MM, Fontes CM, Liporoni P, Mathias P. Microinfiltração na interface de reparo de resina composta sobre diferentes tratamentos da superfície [abstract n. Ia 169]. Pesqui Odontol Bras 2002; 16(sp. Issue):53.

4- Chalkley Y, Chan DCN. Microleakage between light-cured composites and repairs. J Prosthet Dent 1986; 56(4):441-4.

5- Conover NJ. Practical non-parametric statistics. New York : John Wiley and sons; 1980.
6- Denehy G, Bouschlicher M, Vargas M. Intraoral repair of cosmetic restorations. Dent Clin North Am 1998; 42(4):719-37.

7- Hadavi f, Hey JH, Ambrose ER, Elbadrawy HE. Effect of different adhesive systems on microleakage at the amalgam/composite resin interface. Oper Dent 1993; 18(1):2-7.

8- Hollander M, Wolfe DA. Non-parametric statistical methods. New York : John Wiley and sons; 1973.

9- Kupiec KA, Barkmeier WW. Laboratory evaluation of surface treatments for composite repair. Oper Dent 1996; 21(2):59-62.

10- Lewis G, Johnson W, Martin W, Canerdy A, Claburn C, Collier M. Shear bond strength of immediately repaired light-cured composite resin restorations. Oper Dent 1998; 23(3):121-7.

11- Lucena-Martín C, González-López S, Navajas-Rodrígues de Mondelo JM. The effect of various surface treatments and bonding agents on the repaired strength of heat-treated composites. J Prosthet Dent 2001; 86(5):481-8.

12- Mjör IA, Dahl JE, Moorhead JE. Age of restorations at replacement in permanent teeth in general dental practice. ACTA Odontol Scand 2000; 58(3):97-101.

13- Öztas N, Alaçan A, Bardakcy Y. The effect of air abrasion with two new bonding agents on composite repair. Oper Dent 2003; 28(2):149-54.

14- Pett MA. Nonparametric Statistical for Health Care Research. London : Sage Publication; 1997.

15- Pounder B, Gregory WA, Powers JM. Bond strengths of repaired composite resins. Oper Dent 1987; 12(3):127-31.

16- Puckett AD, Holder R, O’Hara JW. Strength of posterior composite repairs using different composite / bonding agent combinations. Oper Dent 1991; 16(4):136-40.

17- Saunders WP. Effect of fatigue upon the interfacial bond strength of repaired composite resins. J Dent 1990; 18(3):158-62.

18- Shahdad SA, Kennedy JG. Bond strength of repaired anterior composite resins: an in vitro study. J Dent 1998; 26(8):685-94.

19- Söderholm, K-JM. Flexure strength of repaired dental composites. Scand J Dent Res 1986; 94(4):364-65.

20- Söderholm K-JM, Roberts MJ. Variables influencing the repair strength of dental composites. Scand J Dent Res 1991; 99(2):17380

21- Shinkai RS, Cury AA, Cury JA. In vitro evaluation of secondary caries development in enamel and root dentin around luted metallic restoration. Oper Dent 2001; 26(1):52-9.

22- Swift Jr. EJ, LeValley BD, Boyer DB. Evaluation of new methods for composite repair. Dent Mater 1992; 8(6):362-5.

23- Turner CW, Meiers JC. Repair of an aged, contaminated indirect composite resin with a direct, visible-light-cured composite resin. Oper Dent 1993; 18(5):187-94. 